\title{
Begomoviruses Associated with Bean Golden Mosaic Disease in Nicaragua
}

\author{
J. Karkashian, Escuela de Biología y Centro de Investigación en Biología Celular y Molecular (CIBCM), Universidad de Costa Rica; \\ E. D. Ramos-Reynoso, CIBCM, Universidad de Costa Rica; D. P. Maxwell, Department of Plant Pathology, University of Wisconsin- \\ Madison 53706; and P. Ramírez, CIBCM, Universidad de Costa Rica
}

\begin{abstract}
Karkashian, J., Ramos-Reynoso, E. D., Maxwell, D. P., and Ramírez, P. 2011. Begomoviruses associated with bean golden mosaic disease in Nicaragua. Plant Dis. 95:901-906.

Begomovirus spp. cause substantial losses in bean crops in tropical and subtropical regions of the Americas. The predominant Begomovirus sp. in Central America associated with golden mosaic symptoms in bean is Bean golden yellow mosaic virus (BGYMV). However, Calopogonium golden mosaic virus was previously found to infect bean crops in the northern region of Costa Rica. The objective of this research was to identify Begomovirus spp. that infect bean plants in different geographical regions of Nicaragua. In all, 126 samples of young bean leaves with symptoms of golden mosaic were collected from eight different regions of Nicaragua. Using DNA hybridization with specific probes, 120 samples tested positive for BGYMV, 14 samples tested

positive for Squash yellow mild mottle virus, and 7 samples tested positive for Calopogonium golden mosaic virus. Sequence analysis of polymerase chain reaction-amplified products from three samples (MA-9 Managua, BE-8 Rivas, and SO-9 Granada) also indicated that the symptoms of golden mosaic in bean are associated with viral sequences from three different Begomovirus spp. Management of bean golden mosaic disease must take into account that BGYMV is the predominant virus ( $95 \%$ of the samples) and that $12 \%$ of the samples exhibited possible mixed infections or recombination events in the south and central geographical regions of Nicaragua.
\end{abstract}

Geminivirus spp. (family Geminiviridae) are the causal agents of substantial losses in bean crops in Latin America and the Caribbean. Twinned isometric particles and circular single-stranded DNA genomes are characteristics of this group $(13,19)$. Within this family, the members of the genus Begomovirus, type species Bean golden yellow mosaic virus (BGYMV), are transmitted by whiteflies (Bemisia tabaci) to dicotyledonous plants (10). The genome is usually divided in two components termed DNA-A and DNA-B. Both components have a common region (CR) of approximately 200 nucleotides, which is nearly identical (nucleotide sequence identity $>90 \%)$ between isolates of the same virus $(15,19,27)$. BGYMV (GenBank accession numbers M91604 and M91605) was reported as the main bean-infecting Begomovirus spp. in Central America (9). However, Calopogonium golden mosaic virus (CalGMV; GenBank, accession number AF439402) (26) is thought to infect bean plants in the northern part of Costa Rica, close to the border with Nicaragua (8).

Geminivirus sp. identification involves the use of molecular methods such as polymerase chain reaction (PCR) with general and specific primers $(24,25,32)$, dot blot hybridization with species-specific probes $(12,24)$, and DNA sequencing (23).

Despite the lack of immune cultivars for the majority of the commercial crops affected by Begomovirus spp., breeding for disease resistance has proven to be the most effective and sustainable of the integrated whitefly-Begomovirus sp. control methods implemented to date (21). For this practice to be successful, it is necessary to obtain information about the degree of diversity among the prevalent viruses (5).

Corresponding author: J. Karkashian,

E-mail: jamesk@biologia.ucr.ac.cr

Accepted for publication 18 November 2010.

doi:10.1094/PDIS-03-10-0165

(C) 2011 The American Phytopathological Society
Bean golden mosaic disease was first observed in Nicaragua in the early 1970s but it was not until 1990 that the disease became economically important. The incidence of golden mosaic symptoms in bean has increased, probably due to the expansion of horticultural crops in the traditional bean-growing areas (22). The objective of this research was to determine the diversity of Begomovirus spp. that infect bean crops in Nicaragua. In this study, BGYMV was detected in all of the regions of Nicaragua that were studied. We also detected viral sequences related to Squash yellow mild mottle virus (SYMMoV, GenBank accession numbers NC003865 and NC003860) $(10,17)$ in the central and southern geographical regions as well as viral sequences related to CalGMV $(8,26)$ in the southern geographical regions close to the border with Costa Rica.

\section{Materials and Methods}

Collection of samples. Young, fully developed, trifoliate leaves from common bean (Phaseolus vulgaris) plants with golden mosaic symptoms were collected from 15 locations in eight regions of Nicaragua during October 2002 (Table 1; Fig. 1). Locations included relatively small, rural bean fields exhibiting high incidence of golden mosaic symptoms, typical of the bean-producing regions in Nicaragua. Disease incidence was determined by visual inspection of 100 plants in a row selected at random.

Total DNA extraction. DNA was extracted from $0.05 \mathrm{~g}$ of leaf tissue by the Dellaporta method (7). Total DNA was suspended in distilled water $(50 \mu \mathrm{l})$ and used in PCR and DNA hybridization procedures.

PCR. Viral DNA was amplified by PCR from 22 samples from eight different geographical regions in Nicaragua. General primers were used to amplify a portion of DNA-A including the CR, as well as partial sequences from the replication-associated protein (rep) gene and the coat protein ( $c p$ ) gene (PARc715/PALv1978), the hypervariable region (HVR) of DNA-B (PBL1v2039/PCRc2) (25), and the $3^{\prime}$ end of the $c p$ gene (PAV494/PAC1048) (32). PCR conditions were as described by Rojas et al. (25): $1.0 \mu \mathrm{l}$ of $25 \mathrm{mM}$ $\mathrm{MgCl}_{2} ; 2.0 \mu \mathrm{l}$ of dATP, dCTP, dTTP, and dGTP at $2.5 \mathrm{mM}$ each; 
$0.5 \mu \mathrm{l}$ of $10 \mathrm{mM}$ each primer; $0.3 \mu \mathrm{l}$ of Taq DNA polymerase (Promega Corp., Madison, WI); $2.0 \mu \mathrm{l}$ of $10 \times$ buffer; $13.2 \mu \mathrm{l}$ of sterile distilled $\mathrm{H}_{2} \mathrm{O}$; and $5 \mu \mathrm{l}$ of sample DNA in $25 \mu \mathrm{l}$. Viral DNA was amplified in a PTC100 thermal cycler (MJ Research Inc., Watertown, MA) for 30 cycles of denaturing, annealing, and extension, with the following conditions: $1 \mathrm{~min}$ at $94^{\circ} \mathrm{C}, 2 \mathrm{~min}$ at $55^{\circ} \mathrm{C}$, and $3 \mathrm{~min}$ at $72^{\circ} \mathrm{C}$. These cycles were followed by a final cycle of $1 \mathrm{~min}$ at $94^{\circ} \mathrm{C}, 2 \mathrm{~min}$ at $55^{\circ} \mathrm{C}$, and $15 \mathrm{~min}$ at $72^{\circ} \mathrm{C}$. PCR products were analyzed by electrophoresis on $1 \%$ agarose gels in $0.5 \times$ Trisborate-EDTA buffer (30). The molecular size marker used was a 1kb DNA ladder (Gibco BRL, Gaithersburg, Maryland).

Dot blot hybridization. Total DNA extracted from 126 samples was analyzed by dot blot hybridization with general and specific probes to detect geminiviral DNA. The AlkPhos Direct Labeling and Detection kit (Amersham Pharmacia, Piscataway, NJ) was used to label a PCR product from the $3^{\prime}$ end of the $c p$ gene of BGYMV as a general probe (24) and PCR products (primer pair PBL1v2039/PCRc2) from an HRV in the DNA-B components of BGYMV, SYMMoV, and CalGMV as specific probes. Hybridizations and washes were carried out at low stringency $\left(55^{\circ} \mathrm{C}\right)$ for the general probe and high stringency $\left(65^{\circ} \mathrm{C}\right)$ for the specific probes, according to Gilbertson et al. (12).

Cloning and sequencing. PCR fragments obtained from DNAA with primer pair PARc715/PALv1978 and from the HVR of DNA-B of three different samples (SO-9 Granada, BE-8 Rivas, and
MA-9 Managua) were cloned using the pBluescript II KS (+) vector (Stratagene, La Jolla, CA). The clones were sequenced using the Big Dye system (Amersham Inc., Cleveland) and an ABI Prism 377 sequencer (Applied Biosystems, Foster City, CA). The se-

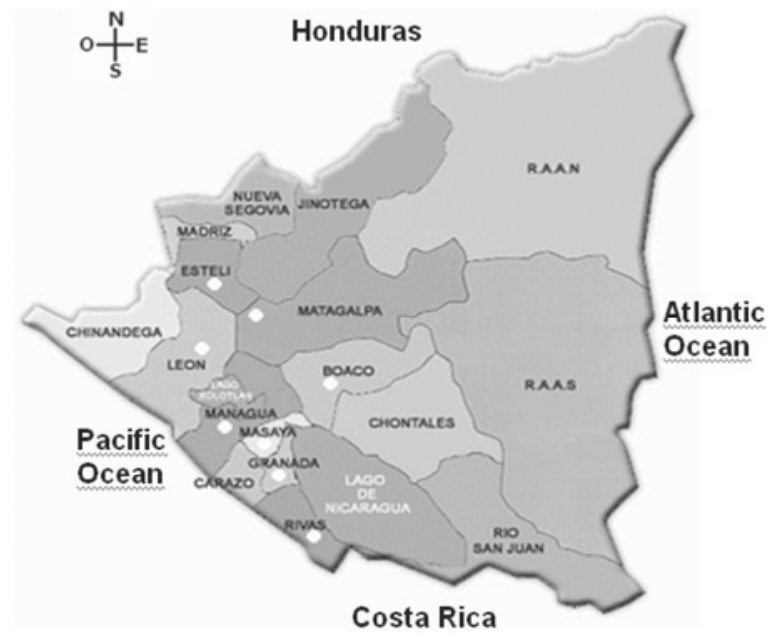

Fig. 1. Map of Nicaragua indicating (white circles) the regions where common bean with symptoms of golden mosaic were collected.

Table 1. Geographical distribution of common bean samples collected in Nicaragua during October 2002

\begin{tabular}{|c|c|c|c|c|}
\hline Region & Location of the fields & Code & No. of samples & Disease incidence in the field \\
\hline \multirow[t]{2}{*}{$\overline{\text { Boaco }}$} & San Lorenzo & & & \\
\hline & El Portón & $\mathrm{PO}$ & 9 & $20 / 100$ \\
\hline Managua & Managua & MA & 11 & $80 / 100$ \\
\hline Granada & San Juan de Oriente & SO & 11 & $75 / 100$ \\
\hline \multirow{4}{*}{ Masaya } & Nindiri & & & \\
\hline & Madrigales Norte & MN & 12 & $90 / 100$ \\
\hline & Madrigales Sur & MS & 10 & $93 / 100$ \\
\hline & Veracruz & VE & 15 & $95 / 100$ \\
\hline Rivas & Belén & $\mathrm{BE}$ & 12 & $10 / 100$ \\
\hline \multirow[t]{2}{*}{ León } & León & LE & 6 & $35 / 100$ \\
\hline & San Jacinto & SJ & 5 & $30 / 100$ \\
\hline \multirow[t]{2}{*}{ Matagalpa } & San Isidro & & & \\
\hline & El Jocote & $\mathrm{JO}$ & 10 & $85 / 100$ \\
\hline \multirow{3}{*}{ Estelí } & Estelí & & & \\
\hline & El Pastoreo & PA & 12 & $40 / 100$ \\
\hline & El Terrero & $\mathrm{TE}$ & 13 & $35 / 100$ \\
\hline
\end{tabular}

Table 2. Sequences of Begomovirus spp. used in comparative and phylogenetic analyses

\begin{tabular}{|c|c|c|c|c|}
\hline \multirow[b]{2}{*}{ No. } & \multirow[b]{2}{*}{ Geminivirus } & \multirow[b]{2}{*}{ Acronym } & \multicolumn{2}{|c|}{ Accession number ${ }^{\mathrm{a}}$} \\
\hline & & & DNA-A & DNA-B \\
\hline 1 & Abutilon mosaic virus & AbMV & X15983 & X15984 \\
\hline 2 & Abutilon mosaic virus-Hawaii & AbMV-HW & U51137 & U51138 \\
\hline 3 & African cassava mosaic virus-Camerún & ACMV-CM & AF112352 & AF112353 \\
\hline 4 & Bean calico mosaic virus & BCaMV & AF110189 & AF110190 \\
\hline 5 & Bean dwarf mosaic virus & BDMV & M88179 & M88180 \\
\hline 6 & Bean golden mosaic virus-Brazil & BGMV & M88686 & M88687 \\
\hline 7 & Bean golden yellow mosaic virus-PR & BGYMV-PR & M10070 & M10071 \\
\hline 8 & Bean golden yellow mosaic virus-DR & BGYMV-DR & L01635 & L01636 \\
\hline 9 & Bean golden yellow mosaic virus-GT & BGYMV-GT & M91604 & M91605 \\
\hline 10 & Bean golden yellow mosaic virus-MX & BGYMV-MX & AF173555 & AF173556 \\
\hline 11 & Calopogonium golden mosaic virus & CalGMV & AF439402 & NA \\
\hline 12 & Pepper huasteco yellow vein virus & PHYVV & X70418 & X70419 \\
\hline 13 & Pepper huasteco yellow vein virus-Sinaloa & PHYVV-Sin & AY044162 & AY044163 \\
\hline 14 & Potato yellow mosaic virus-Guadeloupe & PYMV-GP & AY120882 & AY120883 \\
\hline 15 & Potato yellow mosaic virus-Venezuela & PYMV-VE & D00940 & D00941 \\
\hline 16 & Squash leaf curl virus & SLCV & M38182 & M38183 \\
\hline 17 & Squash yellow mild mottle virus & SYMMoV & AY064391 & AF440790 \\
\hline 18 & Tomato golden mosaic virus & TGMV & K02029 & K02030 \\
\hline
\end{tabular}

a NA indicates that the sequence is not available in the GenBank database. The CalGMV HRV sequence used for the analysis in Figure 3 has not been published. This sequence corresponds to a polymerase chain reaction (PCR) fragment amplified using primer pair PBL1v2039/PCRc2 from a Calopogonium mucunoides plant collected next to a bean field in the northern region of Costa Rica and exhibiting bright golden mosaic symptoms typical of begomoviral infections in hosts of the Fabaceae family. 
quences of both strands were determined using both vector and viral primers.

Sequence analysis. The viral sequences were compared with others available in the GenBank data base (Table 2) using the Blast, Clustal-X, and MEGA version 2.1 programs (18,31). The phylogenetic analyses were done using maximum parsimony with 200 bootstrap replicates with MEGA version 2.1.

\section{Results}

Incidence of golden mosaic symptoms in the bean crops. The incidence of golden mosaic symptoms of bean plants in the different geographical regions varied between 10 and 95\%. The highest incidences were observed in the Masaya region (Table 1), where high populations of whiteflies were also observed.

Amplification of viral DNA by PCR. The PCR fragments of the HVR from 22 samples selected from different regions of Nicaragua showed three different band sizes, which indicated the presence of three different Begomovirus spp. Some samples exhibited two bands, indicating the possibility of mixed infections by two or more Begomovirus spp. (Table 3). The PCR fragments from DNA-A obtained with primer pair PARc715/PALv1978 were approximately $1.4 \mathrm{~kb}$ in all samples.

Detection of viral DNA by dot blot hybridization. Begomoviral DNA was detected in 125 of 126 samples using a general probe (data not shown). Using species-specific probes, BGYMV, SYMMoV, and CalGMV were detected in 120, 14, and 7 samples,

Table 3. Polymerase chain reaction (PCR) products obtained from the hypervariable region of DNA-B, amplified with primer pair PBL1v2039/PCRc2 ${ }^{\mathrm{a}}$

\begin{tabular}{lllc}
\hline Sample & \multicolumn{1}{c}{ Location } & $\begin{array}{c}\text { Sample } \\
\text { code }\end{array}$ & $\begin{array}{c}\text { Size of PCR } \\
\text { products (kb) }\end{array}$ \\
\hline 1 & San Lorenzo el Portón Boaco & PO-7 & $0.3,0.6$ \\
2 & Managua, Managua & MA-9 & $0.3,0.6$ \\
3 & San Juan de Oriente, Granada & SO-6 & 0.3 \\
4 & San Juan de Oriente, Granada & SO-8 & 0.5 \\
5 & San Juan de Oriente, Granada & SO-9 & $0.3,0.5$ \\
6 & Madrigales Norte, Masaya & MN-12 & $0.5,0.6$ \\
7 & Madrigales Sur, Masaya & MS-3 & $0.3,0.6$ \\
8 & Madrigales Sur, Masaya & MS-5 & $0.3,0.6$ \\
9 & Veracruz, Masaya & VE-10 & $0.3,0.5$ \\
10 & Belén, Rivas & BE-1 & $0.5,0.6$ \\
11 & Belén, Rivas & BE-4 & $0.5,0.6$ \\
12 & Belén, Rivas & BE-8 & $0.3,0.5$ \\
13 & San Jacinto, León & SJ-1 & 0.6 \\
14 & San Jacinto, León & SJ-7 & 0.6 \\
15 & El pastoreo, Estelí & PA-6 & 0.6 \\
16 & El terrero, Estelí & TE-1 & 0.6 \\
17 & El terrero, Estelí & TE-6 & 0.6 \\
18 & El Jocote & JO-1 & $0.3,0.6$ \\
19 & El Jocote & JO-2 & $0.3,0.6$ \\
20 & El Jocote & JO-5 & $0.3,0.6$ \\
21 & El Jocote & JO-8 & $0.3,0.6$ \\
22 & El Jocote & JO-9 & $0.3,0.6$ \\
\hline
\end{tabular}

${ }^{a}$ DNA used in PCR reactions was from bean samples exhibiting golden mosaic symptoms, collected during October 2002 in Nicaragua. respectively (Table 4). Mixed infections were detected in 15 samples: nine samples with BGYMV and SYMMoV, three samples with BGYMV and CalGMV, and three samples with SYMMoV and CalGMV. BGYMV was detected in all eight geographical regions sampled, SYMMoV was detected in six regions, and CalGMV was only detected in the southern regions of Masaya, Granada, and Rivas, close to the border with Costa Rica (Table 4).

Sequence analysis of the HVR. The sequence of the HVR from sample MA-9 $(0.6 \mathrm{~kb})$ showed a nucleotide identity lower than $64 \%$ with the sequences of the HVR from samples BE-8 and SO-9 ( 0.3 and $0.5 \mathrm{~kb}$, respectively). The sequences of the $0.3-$ and $0.5-\mathrm{kb}$ fragments from samples BE-8 and SO-9 showed very low nucleotide identity $(32 \%)$ with each other. On the other hand, nucleotide identities between the HVR sequences from samples BE-8 and SO9 were $90 \%$ for the $0.3-\mathrm{kb}$ fragments and $99 \%$ for the $0.5-\mathrm{kb}$ fragments (data not shown).

The 0.6-kb fragment from sample MA-9 showed 85\% nucleotide identity with BGYMV-MX and 79\% with BGYMV-GT (Table 5). The 0.3-kb fragment from sample BE-8 showed $94 \%$ nucleotide identity with SYMMoV, while the $0.5-\mathrm{kb}$ fragment from the same sample showed $84 \%$ nucleotide identity with CalGMV. The $0.3-\mathrm{kb}$ fragment from sample SO-9 showed $87 \%$ nucleotide identity with SYMMoV.

Analysis of a partial DNA-A sequence from PCR fragments obtained using primer pair PARc715/PALv1978. Comparisons based on partial DNA-A sequences corresponding to this PCR product among samples MA-9, BE-8, and SO-9 showed nucleotide identities lower than 64\% (data not shown). Sample MA-9 had over $90 \%$ nucleotide identity with BGYMV, sample BE-8 had nucleotide identities lower than $69 \%$ with all other Begomovirus spp. included in the analysis, and, finally, isolate SO-9 had $93 \%$ nucleotide identity with CalGMV (GenBank accession number AF439402; data not shown). A BLAST search of sample BE-8 at GenBank gave a $77 \%$ nucleotide identity with Potato yellow mosaic virus-GP (PYMV-GP) (GenBank accession number AY120882).

Analysis of sequences from the $\mathbf{5}^{\prime}$ end of the rep gene. The $5^{\prime}$ end of the rep gene from sample MA-9 had nucleotide identities lower than $69 \%$ with the same regions of BE-8 and SO-9 (data not shown) but had $95 \%$ nucleotide identity with BGYMV, specifically the BGYMV isolate from Mexico (BGYMV-MX, GenBank accession number AF173555; Table 5). The nucleotide identities at the $5^{\prime}$ end of the rep gene and its corresponding amino acid similarities were lower than $61 \%$ between BE-8 and SO-9 (data not show). The $5^{\prime}$ end of the rep gene of BE-8 exhibited the highest nucleotide identities and corresponding amino acid similarities (84 and 86\%, respectively) with PYMV-GP, whereas the rep gene of SO-9 showed $93 \%$ nucleotide identity with CalGMV (Table 5).

The potential DNA-binding specificity determinant (SPD) in the deduced Rep protein sequence of BE-8 (PRKGSFSIKA) was identical to that of PYMV-GP. On the other hand, the SPD domain of sample SO-9 (PRNPSSFRLSA) was more similar to that of CalGMV (PRNPNSFRLTA) (Fig. 2) (5).

Sequence analysis of the CR of DNA-A. The CR sequences of samples MA-9, BE-8, and SO-9 had very low nucleotide identities

Table 4. Detection of Begomovirus spp. associated with bean crops in geographical regions in Nicaragua by dot blot hybridization with specific probes ${ }^{\mathrm{a}}$

\begin{tabular}{|c|c|c|c|c|c|c|}
\hline \multirow[b]{2}{*}{ Region } & \multicolumn{3}{|c|}{ Specific probes } & \multicolumn{3}{|c|}{ Mixed infections } \\
\hline & BGYMV & SYMMoV & CalGMV & BGYMV, SYMMoV & BGYMV, CalGMV & SYMMoV, CalGMV \\
\hline León & $11 / 11$ & $0 / 11$ & $0 / 11$ & $0 / 11$ & $0 / 11$ & $0 / 11$ \\
\hline Esteli & $25 / 25$ & $0 / 25$ & $0 / 25$ & $0 / 25$ & $0 / 25$ & $0 / 25$ \\
\hline Boaco & $9 / 9$ & $1 / 9$ & $0 / 9$ & $1 / 9$ & $0 / 9$ & $0 / 9$ \\
\hline Matagalpa & $9 / 10$ & $6 / 10$ & $0 / 10$ & $5 / 10$ & $0 / 10$ & $0 / 10$ \\
\hline Managua & $11 / 11$ & $1 / 11$ & $0 / 11$ & $1 / 11$ & $0 / 11$ & $0 / 11$ \\
\hline Masaya & $36 / 37$ & $3 / 37$ & $2 / 37$ & $2 / 37$ & $1 / 37$ & $1 / 37$ \\
\hline Granada & $8 / 11$ & $2 / 11$ & $2 / 11$ & $0 / 11$ & $0 / 11$ & $1 / 11$ \\
\hline Rivas & $11 / 12$ & $1 / 12$ & $3 / 12$ & $0 / 12$ & $2 / 12$ & $1 / 12$ \\
\hline Total & $120 / 126$ & $14 / 126$ & $7 / 126$ & $9 / 126$ & $3 / 126$ & $3 / 126$ \\
\hline
\end{tabular}

${ }^{a}$ BGYMV = Bean golden yellow mosaic virus, $\mathrm{SYMMoV}=$ Squash yellow mild mottle virus, and CalGMV = Calopogonium golden mosaic virus. 
among themselves (lower than 54\%; data not shown). Sample MA9 had $>97 \%$ nucleotide identity and identical Rep protein recognition elements with BGYMV. Sample BE-8 had the highest nucleotide identity (81\%) with PYMV-GP. Sample SO-9 had $94 \%$ nucleotide identity and identical Rep protein recognition elements with CalGMV (Tables 5 and 6).

Sequence analysis of the $3^{\prime}$ end of the $c p$ gene, obtained with primer pair PAV494/PAC1048. Samples BE-8 and SO-9 shared 97\% nucleotide identity in their $c p$ gene sequences and over $90 \%$ nucleotide identity with CalGMV. Sample MA-9 showed $>97 \%$ nucleotide identity with BGYMV (Table 5).

Phylogenetic analysis. The sequences from the different HVR fragments of DNA-B grouped in three different phylogenetic clusters: the MA-9 0.6-kb fragment was associated with the BGYMV cluster, the BE-8 and SO-9 0.3-kb fragments grouped with the SLCV cluster, and the BE-8 and SO-9 0.5-kb fragments grouped with the unpublished HVR sequence of CalGMV (Fig. 3).

Analysis of the nucleotide sequences from DNA-A showed that sample MA-9 consistently grouped within the BGYMV cluster and sample SO-9 consistently grouped with CalGMV when comparing either rep gene sequences (Fig. 4) or $c p$ sequences (Fig. 5). However, sample BE-8 grouped with the PYMV cluster when comparing rep gene sequences and closer to CalGMV when comparing $c p$ gene sequences (Figs. 4 and 5).

\section{Discussion}

The high disease incidences in the fields observed during this study were probably associated with increases in the populations of insect vectors, due to the high temperature and relative humidity reported during August and November 2002 (16). The life cycle of $B$. tabaci accelerates with temperatures over $25^{\circ} \mathrm{C}$ and relative humidity above $65 \%$ (28).

The HVR region in the genome is highly variable and, thus, very useful in begomoviral characterization $(2,11)$. Our results indicate that the PCR-amplified HVR fragment from sample MA-9 $(0.6 \mathrm{~kb})$ is from a Nicaraguan isolate of BGYMV (BGYMV-NI). On the other hand, HVR fragments obtained from samples BE-8 and SO-9 $(0.3$ and $0.5 \mathrm{~kb})$ could represent sequences from Nicaraguan isolates of SYMMoV (SYMMoV-NI) and CalGMV (CalGMV-NI), respectively. However, these results would need to be confirmed; for example, by the detection of SYMMoV genome sequences other than just the HVR.

There is also a distinct possibility that recombinant viruses arising through mixed infections and containing parts of the SYMMoV and CalGMV genomes are present in these samples. It should be noted that CalGMV has not been established as a viral species by the International Committee on Taxonomy of Viruses, because no full sequence of the viral genome has been published.

Table 5. Nucleotide identities of partial sequences from the replication-associated protein (rep) gene, coat protein ( $c p$ ) gene, common region (CR), and hypervariable region (HVR) from isolates of Nicaragua and other selected Begomovirus spp. ${ }^{a}$

\begin{tabular}{|c|c|c|c|c|c|c|c|c|c|c|c|c|c|c|}
\hline \multirow[b]{3}{*}{ Begomovirus spp. ${ }^{\mathrm{b}}$} & \multicolumn{4}{|c|}{ MA-9 (Managua) } & \multicolumn{5}{|c|}{ BE-8 (Belén, Rivas) } & \multicolumn{5}{|c|}{ SO-9 (San Juan de oriente, Granada) } \\
\hline & \multirow[b]{2}{*}{ rep } & \multirow[b]{2}{*}{$\mathbf{C R}$} & \multirow[b]{2}{*}{$c p$} & \multirow{2}{*}{$\frac{\text { HVR }}{0.6 \mathrm{~kb}}$} & \multirow[b]{2}{*}{ rep } & \multirow[b]{2}{*}{ CR } & \multirow[b]{2}{*}{$c p$} & \multicolumn{2}{|c|}{ HVR } & \multirow[b]{2}{*}{ rep } & \multirow[b]{2}{*}{$\mathbf{C R}$} & \multirow[b]{2}{*}{$c p$} & \multicolumn{2}{|c|}{ HVR } \\
\hline & & & & & & & & $0.3 \mathrm{~kb}$ & $0.5 \mathrm{~kb}$ & & & & $0.3 \mathrm{~kb}$ & $0.5 \mathrm{~kb}$ \\
\hline \multirow{2}{*}{$\overline{\mathrm{CalGMV}}$} & 54.3 & & 73.5 & & 60.8 & & 90.2 & & & 93.2 & & 91.4 & & \\
\hline & $(27.5)$ & 48.4 & $(81.7)$ & 31.5 & $(25.7)$ & 52.9 & $(98.2)$ & 32.2 & $\underline{83.5}$ & $(88.4)$ & 93.6 & (98.2) & 29.9 & $\underline{83.7}$ \\
\hline \multirow[t]{2}{*}{ BGYMV-GT } & 93.4 & & 96.5 & & 71.3 & & 80.2 & & & 56.6 & & 81.0 & & \\
\hline & (95.4) & 97.3 & (93.9) & 78.9 & (66.6) & 53.6 & (88.6) & 34.5 & 39.4 & (26.6) & 50.2 & (88.6) & 31.8 & 39.4 \\
\hline \multirow[t]{2}{*}{ BGYMV-MX } & 95.1 & & 98.6 & & 71.8 & & 79.6 & & & 56.6 & & 80.2 & & \\
\hline & $(97.7)$ & 98.9 & $(\mathbf{9 7 . 3})$ & $\underline{84.9}$ & $(67.5)$ & 54.1 & $(86.0)$ & 35.1 & 38.8 & $(27.0)$ & 49.2 & $(86.0)$ & 31.8 & 38.8 \\
\hline \multirow[t]{2}{*}{ BCaMV } & 54.7 & & 80.1 & & 57.7 & & 79.6 & & & 81.4 & & 80.7 & & \\
\hline & (49.3) & 47.7 & (83.4) & 36.3 & (48.4) & 50.8 & (90.4) & 45.5 & 36.7 & $(47.2)$ & 79.2 & (90.4) & 43.2 & 36.7 \\
\hline \multirow[t]{2}{*}{ BDMV } & 73.9 & & 76.0 & & 75.8 & & 78.6 & & & 59.2 & & 79.6 & & \\
\hline & (75.7) & 67.3 & (81.7) & 33.4 & (71.2) & 57.8 & (88.6) & 40.9 & 42.6 & (27.4) & 54.1 & (88.6) & 36.8 & 42.8 \\
\hline \multirow[t]{2}{*}{ BGMV } & 67.0 & & 78.0 & & 73.6 & & 76.8 & & & 58.2 & & 77.6 & & \\
\hline & $(67.5)$ & 55.2 & $(79.1)$ & 32.9 & $(73.5)$ & 64.8 & $(86.0)$ & 39.8 & 44.7 & $(28.7)$ & 58.1 & $(86.0)$ & 37.5 & 44.5 \\
\hline \multirow[t]{2}{*}{ SYMMoV } & 50.2 & & 78.8 & & 52.8 & & 79.6 & & & 77.1 & & 81.0 & & \\
\hline & $(42.8)$ & 47.0 & (81.7) & 29.1 & (40.6) & 47.4 & (90.4) & 93.6 & 33.1 & (47.6) & 71.1 & $(90.4)$ & $\underline{86.6}$ & 32.9 \\
\hline \multirow[t]{2}{*}{ SLCV } & 51.8 & & 78.0 & & 53.7 & & 79.1 & & & 79.1 & & 79.4 & & \\
\hline & $(45.9)$ & 48.2 & (83.4) & 27.5 & $(45.0)$ & 49.1 & (88.6) & 59.2 & 29.0 & (45.9) & 77.5 & (88.6) & 55.0 & 29.0 \\
\hline \multirow[t]{2}{*}{ PYMV-GP } & 68.4 & & 75.4 & & 83.5 & & 77.4 & & & 56.9 & & 78.0 & & \\
\hline & $(67.1)$ & 59.1 & (81.7) & 41.1 & (85.8) & $\underline{80.5}$ & (86.9) & 31.0 & 41.5 & $(27.0)$ & 51.6 & (86.9) & 28.0 & 41.5 \\
\hline
\end{tabular}

a The $c p$ comparisons correspond to nucleotides 1 to 345 of Calopogonium golden mosaic virus (CalGMV) and rep comparisons correspond to nucleotides 1 to 675 of Bean golden yellow mosaic virus-MX (BGYMV-MX). Numbers in parenthesis represent the percentages of amino acid similarity, with the highest percentages in bold. Underlined numbers represent the highest identity values for variable sequences, such as HVR and CR.

${ }^{\mathrm{b}} \mathrm{BCaMV}=$ Bean calico mosaic virus, BDMV = Bean dwarf mosaic virus, BGMV = Bean golden mosaic virus $-\mathrm{Brazil}$, SYMMoV = Squash yellow mild mottle virus, SLCV = Squash leaf curl virus, and PYMV-GP = Potato yellow mosaic virus-Guadeloupe.

\begin{tabular}{|c|c|c|c|c|c|c|}
\hline & & & 10 & 20 & 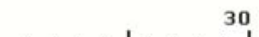 & \\
\hline MA-9 & 1 & Mi & $P P-P Q R F R V$ & QSKNNYFLTYP & RCSIPKEEAL & SQLQKIH - TA \\
\hline $\mathrm{BE}-8$ & 1 & $\mathrm{M}$ & $P R-K G S F S I$ & KAKNYFL TYP & QCSLSKEEAL & EQLKNIK-PP \\
\hline SO-9 & 1 & $\mathrm{M}$ & PR NPS SFRL & SAKNIFL TYP & QCD I SKNEAL & QML QHL QWS V \\
\hline BGMMV & 1 & $\mathrm{M}$ & $P P-P Q R F R V$ & QSKNYFL TYP & RCSIPKEEAL & $S Q L Q K I H-T A$ \\
\hline CalGMV & 1 & $M$ & PRNPNSFRL & TAKNIFLTYP & QCD I SKDEAL & QML QHL HWS V \\
\hline SYMMov & 1 & $\mathrm{M}$ & PRNPKSFRL & TTRNIFLTYP & KCDVPKDEVL & QMLQGL SWS V \\
\hline BDMV & 1 & $\mathrm{M}$ & $P P-P K K F R V$ & QSRNYFL TYP & QCSL TKEEAL & I Q NL K - TP \\
\hline BGMV & 1 & $\mathrm{M}$ & $P P-P K R F K I$ & NAKNYFLTYP & I TKESA I & $E Q L Q N L Q-T P$ \\
\hline PYMV-GP & 1 & $\mathrm{M}$ & PR - K GSFS I & KAKNYFL TYP & HCSL SKEDAL & SQI QNL N - IP \\
\hline PHYN & 1 & $\mathrm{M}$ & $P L$ - PKRFRL & NAKNYFL TYP & QCS I S K & AQLQNL $S-T P$ \\
\hline AbMV & 1 & $\mathrm{M}$ & $P P-P K K F R V$ & QAKNYFL TYP & QCSLTKDEAL & SQLQNLE - TP \\
\hline TGMV & 1 & $\mathrm{M}$ & PSPKRFQI & NAKNYFL TYP & Q CSL SKEESL & $S Q L Q A L N-T P$ \\
\hline
\end{tabular}

Fig. 2. Comparisons of the functional domains of the replication-associated protein (Rep) of isolates from Nicaragua (MA-9, BE-8, and SO-9) and Begomovirus spp. from different phylogenetic groups. Boxed sequence indicates the potential Rep DNA-binding specificity determinant (SPD). Multiple alignments of amino acid sequences were made with the Clustal X program. 
Thus, it is possible that CalGMV is itself a recombinant virus that has become established in a weed host (Calopogonium mucunoides), something that even its partial genome sequences seem to indicate.

Viral DNA obtained from sample MA-9 showed a close relationship with BGYMV isolates. The nearest relationship was with the isolate from Mexico and could be due to the geographical proximity of Nicaragua to the place of identification of this virus in Mexico. Garrido-Ramírez et al. (11) reported that the isolate from Mexico had the highest phylogenetic relationship with the isolate from Guatemala in correlation with geographical proximity.

In this study, we report, for the first time, the possibility of SYMMoV in association with golden mosaic disease of bean crops in Nicaragua, and preliminary results also indicate that it may be associated with begomoviral infections of bean plants in the northern region of Costa Rica (unpublished data). If, indeed, as our results suggest, SYMMoV infects bean crops, this could be due to cultural practices because it is common to find squash plants in the borders of bean fields or even among the rows. This would facilitate the movement of the Begomovirus sp. from one host to the other, because the vector does not fly long distances (14). Another factor that could be involved is the emergence of the B biotype of B. tabaci, which is more polyphagous (1).

The infection of common bean with CalGMV was first reported in the northern regions of Costa Rica (8). In this investigation, CalGMV-related sequences were found in the regions in the southern part of Nicaragua, close to the border with Costa Rica.

Begomovirus spp. present in samples MA-9 and SO-9 exhibited over $90 \%$ nucleotide identities with BGYMV and CalGMV, respectively. For this reason, there is a possibility that MA-9 and SO-9 are Nicaraguan isolates of BGYMV and CalGMV, respectively. This hypothesis must be confirmed with the complete sequences for DNA-A.

The apparent mixed infections observed in this study pose the possibility of recombination and pseudorecombination events, which could result in new viruses. Mixed infections are a prerequisite for recombination but other ecological factors contribute to their establishment (20). In some fields where mixed infections were also detected, the symptoms appeared to be more severe (data not shown). This could indicate an effect of synergism among these viruses. Although this aspect was not evaluated in this investigation, it is considered very important for viral evolution and its effects on cultivated plants.

Sequence analysis indicates that sample BE- 8 may be infected with a recombinant virus. The $5^{\prime}$ end of the $c p$ gene shares over

Table 6. Replication-associated protein (Rep) recognition sequences in the common region (CR) of three Geminivirus isolates from Nicaragua and other selected Geminivirus spp.

\begin{tabular}{|c|c|}
\hline Begomovirus isolates $^{\mathbf{a}}$ & Putative Rep-binding motifs in the $\mathbf{C R}^{\mathrm{b}}$ \\
\hline MA-9 & T- GGAG-AC TGGAG $\ldots . . . . . .$. \\
\hline BE-8 & $\overline{\text { GGGGGAAC T TGGGGAAC. }}$ \\
\hline SO-9 & CTGGTGTCC- TGGTGTC. \\
\hline BGYMV & $\overline{\text { T- GGAG -AC TGGAG } \ldots . . .}$ \\
\hline CalGMV & CTGGTGTCC- TGGTGTC. \\
\hline SYMMoV-CR & T- GGTGTCC- TGGTGTCC. \\
\hline PYMV-GP & TGGGGGAAC $\overline{\text { TGGGGGAAC } . . . . . T A T A ~}$ \\
\hline PHYVV & ATCGGTGTTATCGGTaG...............TATA \\
\hline BDMV & ATTGGAGT -ATTGGAGT $\ldots . . . . . . . .$. TATA \\
\hline AbMV & ATTGGAGT- ATTGGAG …………....TATA \\
\hline BGMV & GGTGT- AATEGTG.... \\
\hline TGMV & GGTAG- TAAGGTAG... \\
\hline
\end{tabular}

${ }^{\mathrm{a}} \mathrm{BGYMV}=$ Bean golden yellow mosaic virus, $\mathrm{CalGMV}=$ Calopogonium golden mosaic virus, SYMMoV-CR = Squash yellow mild mottle virus, $\mathrm{PYMV-GP}=$ Potato yellow mosaic virus-Guadeloupe, $\mathrm{PHYVV}=$ Pepper huasteco yellow vein virus, $\mathrm{BDMV}=$ Bean dwarf mosaic virus, $\mathrm{AbMV}=$ Abutilon mosaic virus, BGMV = Bean golden mosaic virus -Brazil, and TGMV = Tomato golden mosaic virus

${ }^{\mathrm{b}}$ Underlined sequences are direct repeats in each recognition sequence. Bold sequences indicate $\mathrm{G}$ bases present in all repeats.
$90 \%$ nucleotide identity with CalGMV, whereas the $5^{\prime}$ end of the rep gene shows low sequence identity with other Begomovirus spp. $(<75 \%)$, and the Rep protein-binding motif in the CR is similar to PYMV and not CalGMV. The full-length sequence for both DNA$A$ and DNA-B is needed for further characterization of this virus Two HVR fragments of different sizes were detected in this sample, indicating the presence of two DNA-B components. Further analysis of this sample is needed to better characterize the apparent mixed infection.

A host-free period was used as a strategy for management of the whitefly-Begomovirus sp. complex in the Dominican Republic,

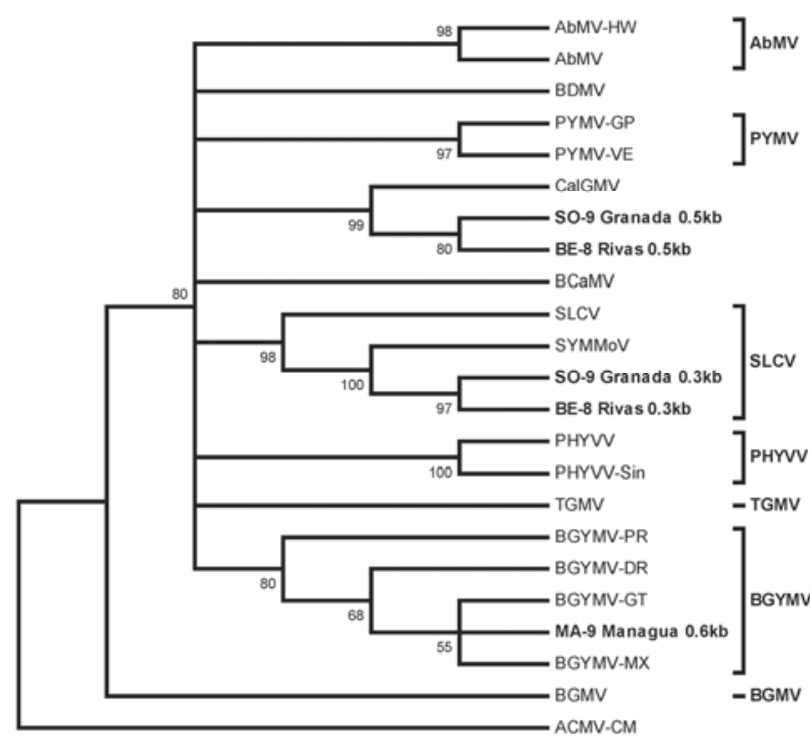

Fig. 3. Phylogenetic analysis indicating relationships among nucleotide sequences of the hypervariable region (HVR) of three bean-infecting Geminivirus spp. from Nicaragua (Managua MA-9, Rivas BE-8, and Granada SO-9) and other selected Begomovirus spp. The tree was made by the method of maximum parsimony with 200 bootstraps. Vertical and horizontal branch lengths are arbitrary. Numbers at the beginning of the branches indicate bootstrap percentages assigned to each node.

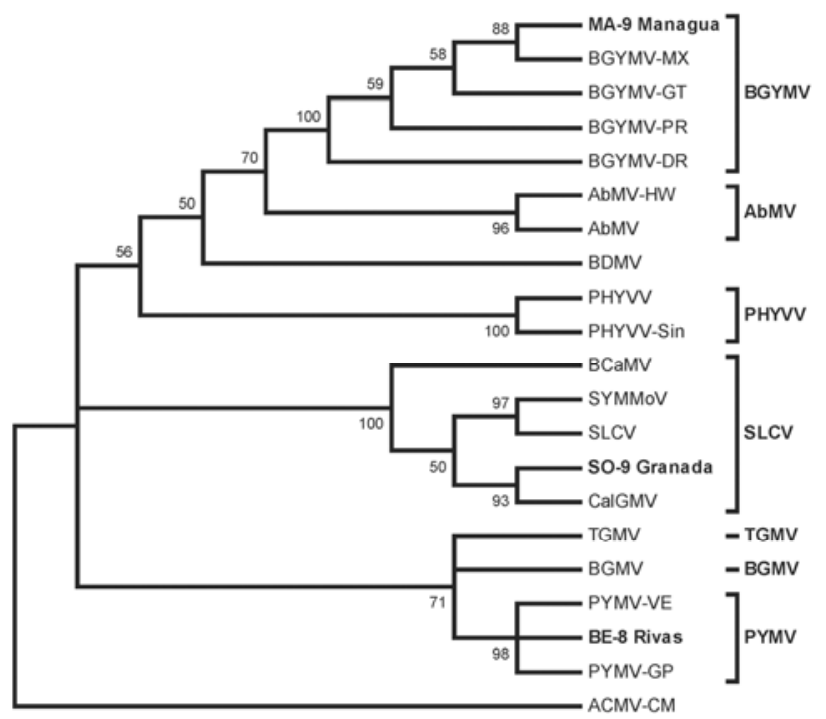

Fig. 4. Phylogenetic analysis indicating relationships among nucleotide sequences of the replication-associated protein gene (675 nucleotides) of three bean-infecting Begomovirus spp. from Nicaragua (Managua MA-9, Rivas BE-8, and Granada SO9) and other selected Begomovirus spp. BGYMV = Bean golden yellow mosaic virus, $\mathrm{AbMV}=$ Abutilon mosaic virus, $\mathrm{PHYVV}=$ Pepper huasteco yellow vein virus, SLCV = Squash leaf curl virus, $\mathrm{TGMV}=$ Tomato golden mosaic virus, BGMV = Bean golden mosaic virus, and PYMV = Potato yellow mosaic virus. The tree was made by the method of maximum parsimony with 200 bootstraps. Vertical and horizontal branch lengths are arbitrary. Numbers at the beginning of the branches indicate bootstrap percentages assigned to each node. 


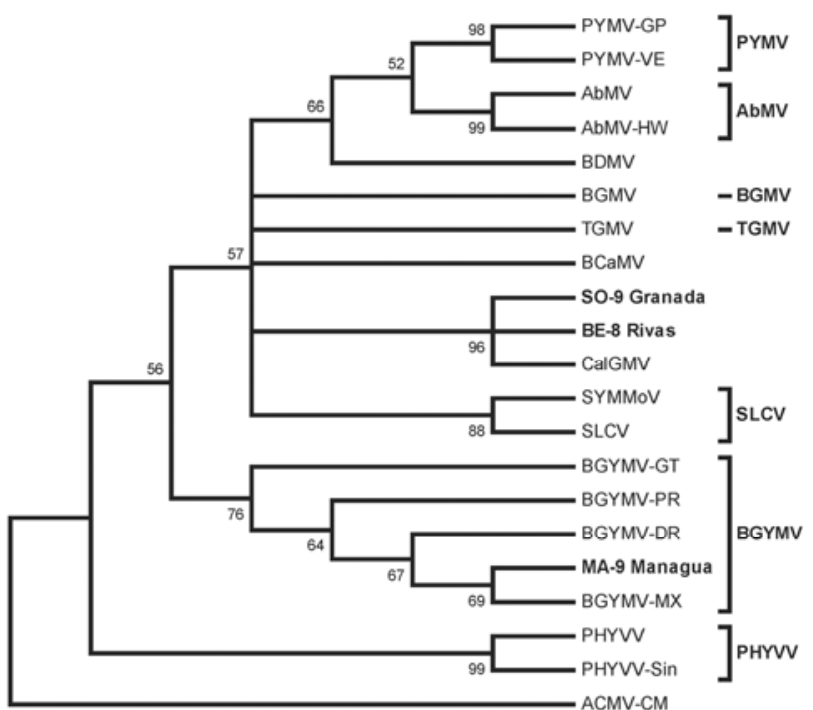

Fig. 5. Phylogenetic analysis indicating relationships among nucleotide sequences of the $5^{\prime}$ region of coat protein gene (345 nucleotides) of three bean-infecting Begomovirus spp. from Nicaragua (Managua MA-9, Rivas BE-8, and Granada SO9) and other selected Geminivirus spp. PYMV = Potato yellow mosaic virus, AbMV = Abutilon mosaic virus, BGMV = Bean golden mosaic virus, $\mathrm{TGMV}=$ Tomato golden mosaic virus, SLCV = Squash leaf curl virus, BGYMV = Bean golden yellow mosaic virus, and PHYVV = Pepper huasteco yellow vein virus. The tree was made by the method of maximum parsimony with 200 bootstraps. Vertical and horizontal branch lengths are arbitrary. Numbers at the beginning of the branches indicate bootstrap percentages assigned to each node.

and it has resulted in substantial yield increases (29). It would be difficult to implement such a strategy in Nicaragua, due to the diverse agroecosystems. A better strategy would be the development of improved cultivars with resistance to Begomovirus spp. (4). This approach requires information about the diversity and distribution of Begomovirus spp. in the country (3).

Approximately $95 \%$ of the samples were infected with BGYMV, which is distributed in all eight regions studied, and in what appear to be mixed infections with SYMMoV (7\%) and CalGMV (2\%) or recombinant viruses bearing sequences related to these viruses. CalGMV sequences were only detected in the southern regions of Nicaragua, close to the border with Costa Rica. This study constitutes the first report of the possibility of SYMMoV or recombinants bearing SYMMoV sequences infecting common bean in the central and southern regions of Nicaragua. Approximately $12 \%$ of the samples exhibited mixed infections of two Begomovirus spp. Sample BE-8 appeared to be a mixed infection and the sequence data for DNA-A indicated that it is likely a recombinant virus. The nature of the Begomovirus spp. associated with sample BE-8 is unclear and needs further investigation.

The possible presence of CalGMV and SYMMoV in the beanproducing regions of Managua, Matagalpa, Masaya, Granada, and Rivas should be considered in the design of strategies for integrated pest management of the whitefly-Begomovirus sp. complex.

\section{Literature Cited}

1. Bedford, I. D., Briddon, R. W., Brown, J. K., Rosell, R., and Markham, P. 1994. Geminivirus transmission and biological characterization of Bemisia tabaci (Gennadius) biotypes from different geographical regions. Ann. Appl. Biol. 125:311-325.

2. Bracero, V., Rivera, L. I., and Beaver, J. S. 2003. DNA analysis confirms Macroptilium lathyroides as alternative host of Bean golden yellow mosaic virus. Plant Dis. 87:1022-1025.

3. Brown, J. K. 2000. Molecular markers for the identification and global tracking of whitefly vector-begomovirus complexes. Virus Res. 71:628-633.

4. Coyne, D. P., Steadman, J. R., Godoy-Lutz, G., Gilbertson, R. L., ArmaudSantana, E., Beaver, J. S., and Myers, J. R. 2003. Contributions of the bean/ cowpea CRSP to management of bean diseases. Field Crop. Res. 82:155-168.

5. Dasgupta, A., Sinha, S. K., and Praveen, S. 2004. Structure of replication initiator protein unites diverse viruses causing tomato leaf curl disease (ToLCD). Plant Sci. 166:1063-1067.

6. Dasgupta, I., Malathi, V. G., and Mukherjee, S. K. 2003. Genetic engineer- ing for virus resistance. Curr. Sci. India 84:341-354.

7. Dellaporta, S. L., Wood, J., and Hicks, J. 1983. A plant DNA minipreparation version II. Plant Mol. Biol. Rep. 1:19-21.

8. Díaz, M., Maxwell, D. P., Karkashian, J. P., and Ramírez, P. 2002. Calopogonium golden mosaic virus identified in Phaseolus vulgaris from western and northern regions of Costa Rica. Plant Dis. 86:188.

9. Faria, J. C., Gilbertson, R. L., Hanson, S. F., Morales, F. J., Ahlquist, P., Loniello, A. O., and Maxwell, D. P. 1994. Bean golden mosaic geminivirus type II isolates from the Dominican Republic and Guatemala: nucleotide sequences, infectious pseudorecombinants, and phylogenetic relationships. Phytopathology 84:321-329.

10. Fauquet, C. M., Bisaro, D. M., Briddon, R. W., Brown, J. K., Harrison, B. D., Rybicki, E. P., Stenger, D. C., and Stanley, J. 2003. Revision of taxonomic criteria for species demarcation in the family Geminiviridae, and an updated list of Begomovirus species. Arch. Virol. 148:405-421.

11. Garrido-Ramírez, E. R., Sudarshana, M. R., and Gilbertson, R. L. 2000 Bean golden mosaic virus from Chiapas, Mexico: characterization, pseudorecombination with other bean-infecting geminivirus and germ plasm screening. Phytopathology 90:1224-1232.

12. Gilbertson, R. L., Hidayat, S. H., Martínez, R. T., Leong, S. A., Faria, J. C Morales, F. J., and Maxwell, D. P. 1991. Differentiation of bean-infecting geminiviruses by nucleic acid hybridization probes and aspects of bean golden mosaic in Brazil. Plant Dis. 75:3336-342.

13. Harrison, B. D., Barker, H., Bock, K., Guthrie, E., Meredith, G., and Atkinson, M. 1977. Plant viruses with circular single-stranded DNA. Nature 270:760-762.

14. Hilje, L. 1995. Aspectos bioecológicos de Bemisia tabaci en Mesoamérica. Manejo Integrado de Plagas 35:46-54.

15. Howarth, A. J., Caton, J., Bossert, M., and Goodman R. M. 1985. Nucleotide sequence of bean golden mosaic virus and a model for gene regulation in geminivirus. Proc. Natl. Acad. Sci. USA 82:3572-3576.

16. INETER ("Instituto Nicarag ense de Estudios Territoriales"). 2002. Temperature and relative humidity records in Nicaragua for the year 2002. June 5, 2004. http://www.ineter.gob.ni

17. Karkashian, J. P., Maxwell, D. P., and Ramírez, P. 2002. Squash yellow mottle geminivirus: a new cucurbit-infecting geminivirus from Costa Rica. (Abstr.) Phytopathology 92:S125.

18. Kumar, S., Tamura, K., Jakobsen, I. B., and Nei, M. 2001. MEGA2: Molecular Evolutionary Genetics Analysis software. Arizona State University, Tempe.

19. Lazarowitz, S. G. 1992. Geminiviruses: genome structure and gene function. Crit. Rev. Plant Sci. 11:327-349.

20. Monci, F., Sáchez-Campos, S., Navas-Castillo, J., and Moriones, E. 2002. A natural recombinant between the geminiviruses tomato yellow leaf curl Sardinia virus and tomato yellow leaf curl virus exhibits a novel pathogenic phenotype and is becoming prevalent in Spanish populations. Virology 303:317-326.

21. Morales, F. J. 2001. Breeding for Resistance to Whitefly-Transmitted Geminiviruses. CIAT, Cali, Colombia.

22. Morales, F. J., and Anderson, P. K. 2001. The emergence and dissemination of whitefly-transmitted geminiviruses in Latin America. Arch. Virol. 146:415-441.

23. Padidam, M., Beachy, R. N., and Fauquet, C. M. 1995. Classification and identification of geminivirus using sequence comparisons. J. Gen. Virol. 76:249-263.

24. Potter, J. L., Nakhla, M. M., Mejía, L., and Maxwell, D. P. 2003. PCR and DNA hybridization methods for specific detection of bean-infecting begomoviruses in the Americas and Caribbean. Plant Dis. 87:1205-1212.

25. Rojas, M. R., Gilbertson R. L., Russell, D. R., and Maxwell, D. P. 1993 Use of degenerate initiators in the polymerase chain reaction to detect whitefly-transmitted geminiviruses. Plant Dis. 77:340-347.

26. Rojas, M. R., Karkashian, J. P., and Maxwell, D. P. 1992. Characterization of geminivirus infecting bean and Calopogonium sp. in Costa Rica. Bean Improv. Coop. 35:150.

27. Rybicki, E. P., Briddon, R. W., Brown, J. K., Fauquet, C. M., Maxwell, D. P., Harrison, B. D., Markham, P., Bisaro, D. M., Robinson, D. J., and Stanley, J. 2000. In family Geminiviridae. Pages 285-297 in: Seventh Rep. Int. Committee on Taxonomy of Viruses. Academic Press, San Diego, CA

28. Salas, J., Mendoza, O., and Arnal, E. 1994. Manejo integrado de la mosca blanca en Venezuela. Fonaiap Divulga No. 45.

29. Salati, R., Nahkla, M., Rojas, M., Guzman, P., Jaquez, J., Maxwell, D., and Gilbertson, R. 2002. Tomato yellow leaf curl virus in the Dominican Republic: characterization of an infectious clone, virus monitoring in whiteflies, and identification of reservoir hosts. Phytopathology 92:487-496.

30. Sambrook, J., Fritsch, E. F., and Maniatis, T. 1989. Molecular Cloning: A Laboratory Manual, 2nd ed. Cold Spring Harbor Laboratory Press, Cold Spring Harbor, NY.

31. Thompson, J., Gibson, T., Plewniak, F., Jeanmougin, F., and Higgins, D 1997. The Clustal X windows interface: flexible strategies for multiple sequence alignment aided by quality analysis tools. Nucleic Acids Res. 25:4876-4882.

32. Wyatt, S., and Brown, J. K. 1996. Detection of subgroup III geminiviruses isolates in leaf extracts by degenerate initiators and polymerase chain reaction. Phytopathology 86:1288-1293. 